zations, BMIJ, (2020), 8(4): 37-49 doi: http://dx.doi.org/10.15295/bmij.v8i4.1703

\title{
ENVIRONMENTALISM AND ETHICAL DECISION MAKING IN BUSINESS ORGANIZATIONS ${ }^{1}$
}

Ahmet COŞKUN 2

ABSTRACT

Keywords:

Ethical Decision Making,

Environmentalism,

Theory of Planned Behaviour

JEL Codes:

M14, Q51

\author{
Received Date (Başvuru Tarihi): \\ Accepted Date (Kabul Tarihi): \\ Published Date (Yayın Tarihi):
}

$19 / 03 / 2020$

$23 / 09 / 2020$

$10 / 12 / 2020$

\section{ÇEVRECİLIK VE İŞLETMELERDE AHLAKÎ KARAR ALMA}

$\ddot{O Z Z}$

\section{Anahtar Kelimeler: \\ Ahlaki Karar Verme, \\ Çevrecilik,}

Planlanmış Davranış Kuramı

JEL Kodlar:

M14, Q51
Bu çalışma, planlanmış davranış kuramı bağlamında, çevresel konularla ilgili ahlaki iş kararlan verme sürecinin dinamiklerini ortaya çıkarmaya çalışmaktadır. Bunun için İIBF bölümlerinde okuyan 167 üniversite öğrencisi ile anket yöntemiyle saha araştırması yapılmış ve elde edilen veriler istatistik paket programı vasıtasıla istatistiki analize tabi tutulmuştur. Sonuçlar, ahlakî davranış niyetlerinin çevrecilik, çevreye yönelik ahlaki tutumlar ve algılanan davranışsal kontrol ile anlamlı pozitif ilişkilere sahip olduğunu göstermiştir. Demografik faktör gruplarının hiçbir değişkende anlamlı farklılı göstermediği görülmüştür.

\footnotetext{
${ }^{1}$ This article is an extended and improved version of the paper published in the proceedings of The 19th International Business Congress hosted by Erciyes University.

2 Asst. Prof., Erciyes University, ahmetcoskun@erciyes.edu.tr,

https://orcid.org/0000-0002-3209-385X
}

Business \& Management Studies: An International Journal Vol.:8 Issue:4 Year:2020, 37-49

Bu makale, araştırma ve yayın etiğine uygun hazırlanmış ve tiinhenticate intihal taramasından geçirilmiştir. 


\section{INTRODUCTION}

As a result of increasing environmental problems such as global warming, depletion of natural resources, mismanagement of hazardous waste etc., especially in recent years, environmental concerns are taken more seriously in all aspects of life, including business realm. Corporates are one of the dominant agents who have the highest level of ecological footprints by their consumption, production and distribution habits.

Accordingly, they are the main responsible of the current environmental problems, and they are the key solution actors, as well (Porter \& Kramer, 2011: 4). In terms of social responsibility activities, social innovation efforts and stakeholder approach, they are amongst the key actors to deal with ecological issues. Thus, business scholars shed light on the ethical decisions in organizations considering the environmental problem, as well (Banerjee, 2002:177).

\section{CONCEPTUAL FRAMEWORK}

Discussing the ethical concerns of business organizations, it is essential to stress on the ethical dispositions of current and prospective human resources of these organizations. So, in order to understand the determinants of ethical behaviours, this study focuses on environmentalism and tries to reveal its relationship with the ethical decision-making process in a business context.

\subsection{Environmentalism}

Most of the recent environmental incidents and evidence show that the conclusions of our current economic choices are not promising for a sustainable life in nature. As one of the many reasons, Dunlap (1980:5) asserted that social sciences had neglected the interconnectivity of human beings with their biophysical surroundings, for a long time. Along with the enlightenment and industrialization process, this approach gave birth to an anthropocentric point of view, especially in developed western countries, namely in Europe and North America (de Anguita et al., 2008:159).

Turkish people, as a part of modern Europe citizens, have been vastly affected by this worldview as well, specifically along with the compulsory education service 
and globalized neoliberal business life. Hence, it is essential to disclose the relationship between environmental attitudes and ethical behaviours, in order to diminish the negative consequences of our business decisions on our very surrounding environment.

When it comes to environmentalism, people have individual worldviews in between two opposite ends, i.e. anthropocentric and ecocentric. While anthropocentric worldview puts the humans at the core of the relationship between nature and humans, recognizes the humans as the conqueror and owner of the whole nature, ecocentric worldview, on the other hand, evaluates the humans as almost an ordinary natural existence, puts the environment at the centre of this relationship, and tries to find a sustainable balance in the relationship between us and the rest of nature.

Anthropocentric worldview is either deliberately, or subconsciously acknowledged as the right approach, widespread. However, anthropocentric worldview assumes that there is no need for conservation of natural resources since they are abundant (White, 1967:1205). As a result, people mostly neglect the sustainability of these vital resources and eventually suffer from environmental problems altogether which are dramatically explained by Hardin (1968:1243-1248) as "tragedy of commons".

Subsequently, environmentalism has been gaining more attention from scholars and practitioners in recent decades. There are several studies published to unveil the environmentalism and its relationships with decision making and behaviour processes in business life (Harmes, 2011; Strasser, 2011; Kopnina, 2014).

\subsection{Ethical Business Decisions}

Ethical decision making in business life has gained importance after the 1980s, and scholars proposed several decision-making models. To name a few of them, Ferrell and Gresham (1985), Rest (1986), Hunt \& Vittell (1986), Trevino (1986) and Jones (1991) were amongst the pioneers in the field. Since then, there were hundreds of articles published about ethical decision making in business organizations. Most of them benefited from a few theoretical models such as Kohlberg's Theory of cognitive moral development (1981), Ajzen's Theory of planned behaviour (1985), Graham's principled 
organizational dissent theory (1986), Rutledge and Karim's agency theory (1999), and Gillian's ethic of care approach (1993).

Dubinsky and Loken (1989) were the first to explore the ethical decision-making process in the Theory of planned behaviour framework. Including their research, many studies showed that there is not a definite relationship between intention and behaviour, but the intention is still a valid predictor of behaviour, and there is still need for additional exploration (O'Fallon \& Butterfield, 2005:399-400).

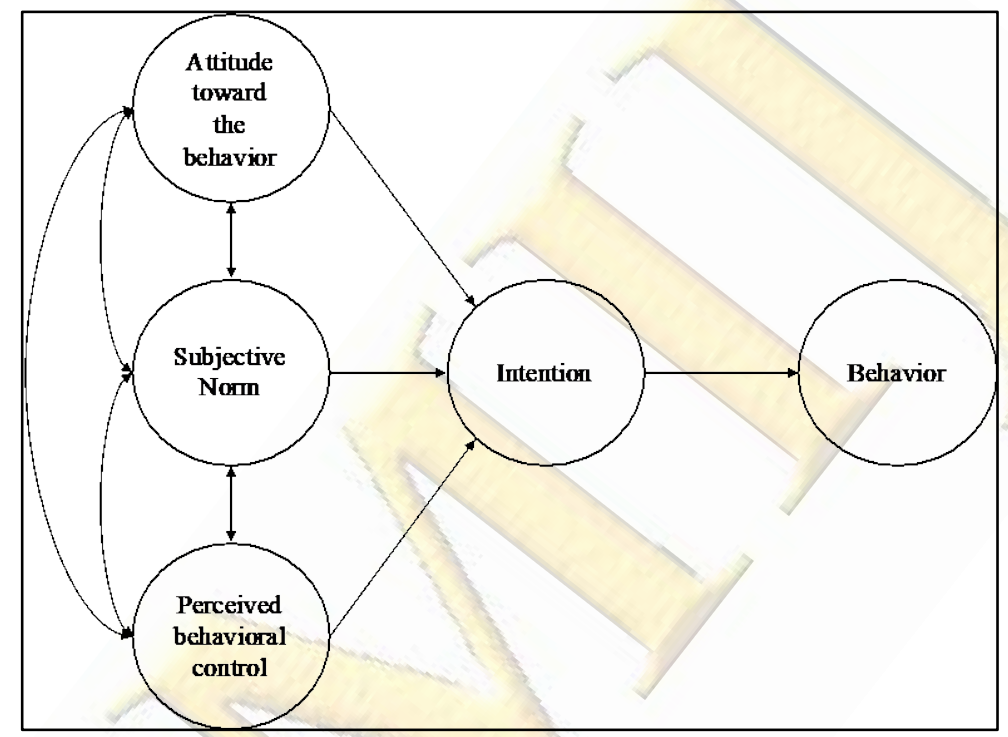

Figure 1. Theory of Planned Behavior

Source: Ajzen, 1991, p. 182

According to the Theory of planned behaviour (Ajzen, 1991:181), the intention is the most significant determinant of individual behaviour. Thus, understanding the intention would provide a full explanation of future behaviour. Further, there are three other variables which have influences on a behavioural intention, i.e. attitudes, subjective norms and perceived behavioural control, yet to be studied enough to explain the structure of the decision-making process.

\section{RESEARCH METHODOLOGY}

Corresponding the necessities mentioned above, this study tries to reveal the dynamics between environmental dispositions and ethical business decisions of university students. To do so, environmentalism level of students is measured by using New Ecological Paradigm Scale, and their environmental, ethical decisions are analyzed by using an ethical decision-making vignette, created in terms of Theory of 
Planned Behavior framework. One hundred eighty-five university students participated in the questionnaire survey study. Some of the responses were removed from the analysis in order to get rid of incorrectly or unthoughtfully replied questions. Ethics committee approval was not provided for the study, as the field survey was held in 2019.

There are several examples of previous studies to measure environmentalism which were done with university students (Thapa, 1999; Bechtel et al., 1999; Iş1ldar, 2008; Erdoğan, 2009; İnal and İnal, 2010; Aytaç and Öngen, 2012). Similarly, this study used the survey method by doing an online questionnaire with university students who are enrolled in different programs in Economics and Administrative Sciences Faculty at Erciyes University.

Table 1. Environmentalism (NEP) Scale Items

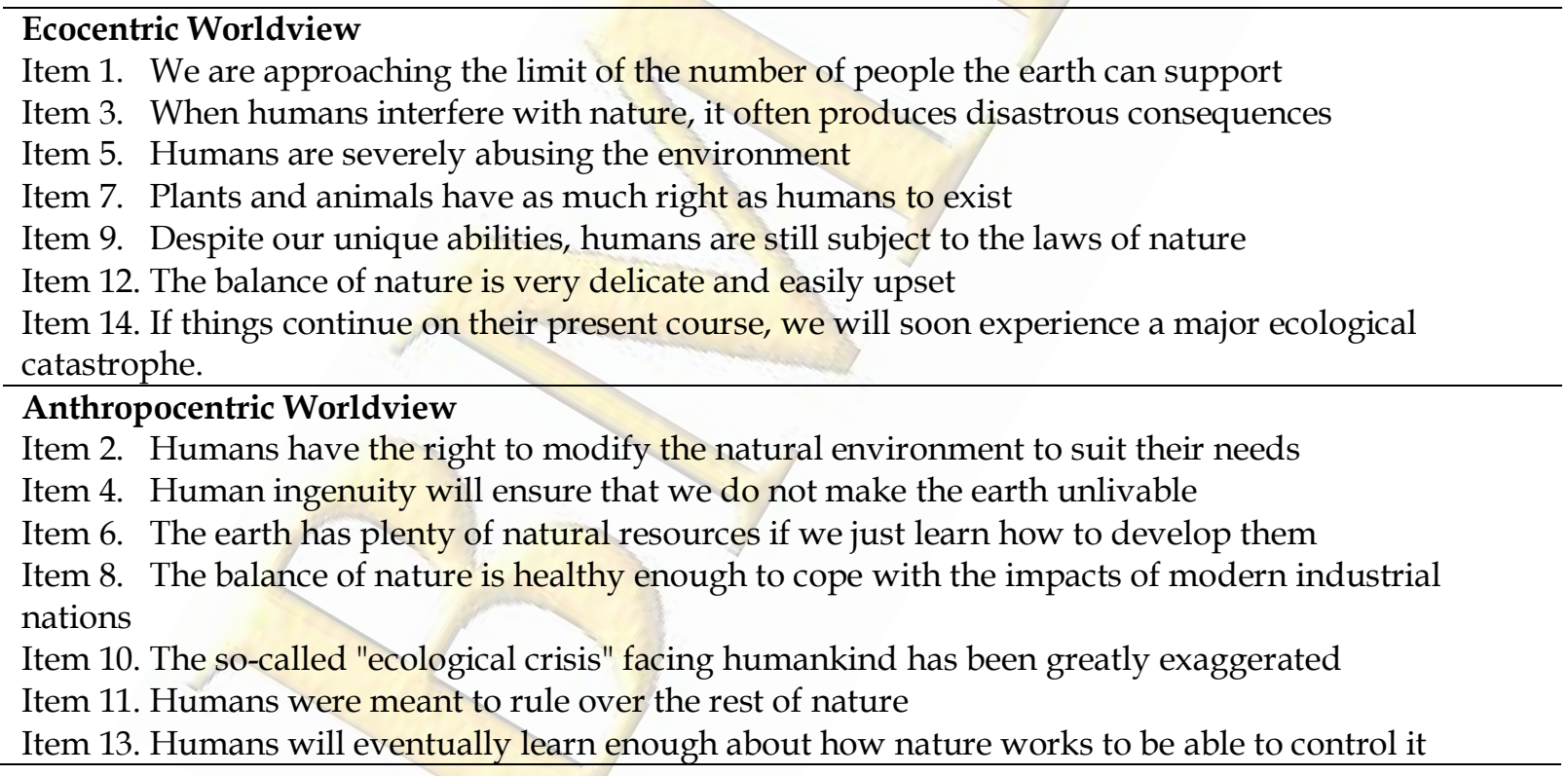

The online questionnaire was comprised of three sections. The first section included a new ecological paradigm (NEP) scale items, which are shown in Table 1, to measure the environmentalism level of respondents. The original NEP scale was developed and revised by Dunlap et al. (2000) and translated into Turkish by Aytaç and Öngen (2012). The second section comprised an ethical decision-making vignette about environmental issues in a business case. In order to create this vignette and questions, the survey instrument developed by Flannery and May (2000:662) was 
benefited from. After reading a real business life scenario happening in an industry company, respondents as fictive junior quality associates of the company were asked to make an ethical decision, to disclose their behavioural intention. They were also asked to respond some questions about their behavioural attitudes, subjective norm and perceived behavioural control, to measure the relevant aspects as antecedents of their ethical behaviour. Both in NEP scale items and ethical decision-making items, 5Point Likert type scales were used. Finally, some demographic questions were asked in the third section of the questionnaire.

By the Theory of planned behaviour, the theoretical model of this study, shown in Figure 2, assumes that ethical intention of a person has significant relationships with his/her attitudes, subjective norms and perceived behavioural control. Additionally, environmentalism level of the person would also have significant relationships with the rest of the components of the model.

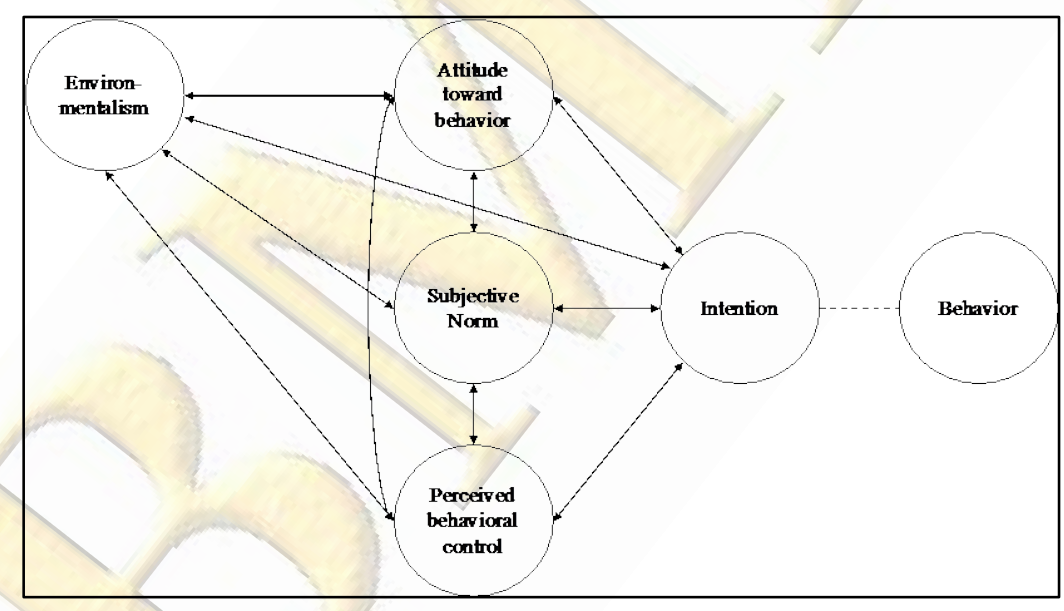

Figure 2. Theoretical Model of the Study

Correspondingly, the main hypotheses of the study are the following:

$\mathbf{H}_{1}$ : Environmentalism has a positive effect on the Ethical Behavior Intentions.

$\mathbf{H}_{2}$ : Environmental Ethics Attitude has a positive effect on the Ethical Behavior Intentions.

$\mathbf{H}_{3}$ : Subjective Norm has a positive effect on the Ethical Behavior Intentions.

$\mathrm{H}_{4}$ : Perceived Behavioral Control has a positive effect on the Ethical Behavior Intentions. 


\section{FINDINGS AND DISCUSSION}

As shown in Table 2., almost two-thirds of the respondents were female, and one-third of them were male students. The classes that students enrolled were, to some degree, homogenously distributed.

Table 2. Frequencies of Respondents

\begin{tabular}{ccc}
\hline Category & Frequency & $\%$ \\
\hline Gender & & \\
M & 63 & 37.7 \\
F & 104 & 62.3 \\
Total & 167 & 100 \\
\hline Class & & \\
1 & 27 & 16.2 \\
2 & 62 & 37.1 \\
3 & 34 & 20.4 \\
$4+$ & 44 & 26.3 \\
Total & 167 & 100 \\
\hline
\end{tabular}

The NEP scale, attitude toward ethical behaviour, subjective norm, perceived behavioural control and behavioural intention were tested with normality and reliability indicators to continue doing further analyzes (Table 3). According to Tabachnick and Fidell's criteria (2013:80), the skewness and kurtosis values should be between -1.5 and 1.5 values, so each variable in the study is usually distributed. Also, the scales should have a Cronbach's Alpha value higher than .60 (Hair et al., 2010:356), and all scales in the study provided the reliability necessity -reliability analysis could not be done for intention variable as it has only one item. Also, regarding the results of factor analysis, Item 6 was excluded from the NEP scale due to its low-level factor load (below .30).

Table 3. Normality and Reliability Test Statistics

\begin{tabular}{lccc}
\hline Variables & Skewness & Kurtosis & Cronbach's Alpha \\
\hline Environmentalism & -.116 & -.630 & .652 \\
Attitude & 1.349 & 1.250 & .632 \\
Subjective Norm & .091 & -.731 & .613 \\
Perceived Behavioral Control & -.602 & -.489 & .767 \\
Intention & 1.001 & .090 & -
\end{tabular}


Mean and standard deviation values of each item are shown in Table 4. Environmentalism level of students was almost 4 point (3.91) which means the respondents have a considerable amount of environmental awareness. Environmental ethics attitude items (which were reversely coded) were found pretty high, as well. Subjective norm values differed in two different items. Subjective Norm-1 was about important people in their surroundings, while Subjective Norm-2 was about important people in their workplaces. Thus, respondents thought the people in their surroundings (2.12) would not put as much pressure on them, as the people in their workplaces (3.26), to lead them to make an unethical decision. Additionally, perceived behavioural control values are around 4 point (4.03), which show the respondents feel adequate to make their own ethical decisions and act correspondingly. Finally, ethical behaviour intention score (reverse coded) is below 2 point (1.93), which means the respondents were eager to do ethical behaviors.

Table 4. Descriptive Statistics

\begin{tabular}{lcc}
\hline & Mean & Std. Deviation \\
\hline Environmentalism & 3.91 & .45 \\
Item 1. & 3.75 & 1.17 \\
Item 2. & 4.11 & 1.35 \\
Item 3. & 3.78 & 1.08 \\
Item 4. & 3.12 & 1.22 \\
Item 5. & 4.59 & .73 \\
Item 7. & 4.88 & .49 \\
Item 8. & 2.31 & 1.24 \\
Item 9. & 4.39 & .78 \\
Item 10. & 4.11 & 1.01 \\
Item 11. & 4.22 & 1.09 \\
Item 12. & 3.57 & 1.15 \\
Item 13. & 3.23 & 1.18 \\
Item 14. & 4.78 & .50 \\
\hline Environmental Ethics Attitude * & 1.50 & .67 \\
Environmental Ethics Attitude -1 & 1.41 & .83 \\
Environmental Ethics Attitude -2 & 1.80 & 1.11 \\
Environmental Ethics Attitude -3 & 1.28 & .65 \\
\hline Subjective Norm ** & 2.69 & 1.14 \\
Subjective Norm -1 & 2.12 & 1.20 \\
Subjective Norm -2 & 3.26 & 1.48 \\
\hline Perceived Behavioral Control & 4.03 & .80 \\
Perceived Behavioral Control -1 & 4.03 & .92 \\
Perceived Behavioral Control -2 & 4.14 & .90 \\
Perceived Behavioral Control -3 & 3.91 & 1.09 \\
\hline Ethical Behavior Intention *** & 1.93 & 1.09 \\
\hline
\end{tabular}


According to the correlation matrix environmentalism level of respondents has significant relationships with their attitudes (-.211) and their behavioural intentions (.165). This result makes sense because environmentalism shows the mindset of people about environment-human relationships. People who have high environmentalism level would be expected to have a low level of unethical attitudes and behavioural intentions, as found in the study.

Table 5. Correlation Matrix

\begin{tabular}{lccccc}
\hline Variables & $\mathbf{1}$ & $\mathbf{2}$ & $\mathbf{3}$ & $\mathbf{4}$ & $\mathbf{5}$ \\
\hline (1) Environmentalism & 1 & & & & \\
(2) Environmental Ethics Attitude & $\mathbf{- . 2 1 1 ^ { * * }}$ & 1 & & & \\
(3) Subjective Norm & .034 & $\mathbf{. 1 7 6 ^ { * }}$ & 1 & & \\
(4) Perceived Behavioral Control & .150 & $\mathbf{- . 4 4 8 ^ { * * }}$ & $-\mathbf{. 2 2 1 ^ { * * }}$ & 1 & \\
(5) Ethical Behavior Intention & $\mathbf{- . 1 6 5 *}$ & $\mathbf{. 6 1 9 * *}$ & .058 & $\mathbf{- . 5 4 0 ^ { * * }}$ & 1 \\
**. Correlation is significant at the 0.01 level (2-tailed). $^{*}$ & & & & \\
*. Correlation is significant at the 0.05 level (2-tailed). & & & & &
\end{tabular}

Subjective norm was found to have a significant positive relationship (.176) with environmental ethics attitudes, which is again expected according to the Theory of planned behaviour. Also, environmental ethics attitude has strong relationships with ethical behaviour intention (.619). The results have proven that behaviours and attitudes are strongly bound together.

Furthermore, perceived behavioural control have significant relationships with environmental ethics attitude (-.448) and ethical behaviour intention (-540). The results have shown that people are more prone to have individual ethical attitudes and act in ethical behaviours if they feel empowered.

Table 6. Regression Analysis

\begin{tabular}{lccccc}
\hline Variables & $\boldsymbol{\beta}$ & $\mathbf{t}$ & $\mathbf{S i g}$ & Tolerance & VIF \\
\hline Constant & & 4.716 & .000 & & \\
Environmentalism & -.009 & -.146 & .884 & .945 & 1.058 \\
Environmental Ethics Attitude & $\mathbf{. 4 8 0 ^ { * }}$ & 7.434 & .000 & .770 & 1.298 \\
Subjective Norm & -.102 & -1.750 & .082 & .937 & 1.067 \\
Perceived Behavioral Control & $-.347^{*}$ & -5.384 & .000 & .774 & 1.292 \\
\hline \multicolumn{4}{c}{ *. Significant at the 0.01 level, Dependent behaviour: Ethical Behavior Intention }
\end{tabular}

When multiple linear regression analysis applied to variables, the model was found significant (Sig.: .000) and explained a considerably high amount of the different independent variable (R: .693). The results of the regression are shown in the below table. Accordingly, environmental ethics attitude of the participants found to have a 
positive effect on the ethical behaviour intentions, and perceived behavioural control has a significant negative effect. However, environmentalism and subjective norm did not appear to have a significant effect on ethical behaviour intention. So, half of the study's hypotheses were statistically supported according to regression analysis.

Table 7. Hypotheses Results

\begin{tabular}{ccc}
\hline Hypothesis & Proposed Relationship & Result \\
\hline H1 & Positive & Not supported \\
H2 & Positive & Supported \\
H3 & Positive & Not supported \\
H4 & Positive & Supported \\
\hline
\end{tabular}

Finally, according to T-test and ANOVA analysis results, no significant differences was found between either gender or enrolled class groups, in terms of the variables above.

\section{CONCLUSION}

As environmental issues are rising rapidly all around the world, business organizations should pay more attention to their ecological impact, as one of the most influential social actors. Strengthening the environmental awareness of their current employees and recruiting environmentally sensitive staff is as important as designing the processes and policies in concordance with ecological concerns. This study reveals that people with higher levels of environmentalism, ethical attitudes and behavioural control perceptions would be more eager to have ethical behaviour intentions. Also, while environmental ethics attitude and perceived behaviour control variables are signs explaining the difference in the ethical behaviour intention, environmentalism and subjective norm variables were not found to have a significant effect. These findings are partly confirming the previous studies, which have found significant effects of environmentalism and proposed antecedents of on ethical behaviour intentions according to planned behaviour theory.

To mention the limitations of the study, due to the time constraint, a survey was applied only to students who are enrolled in a particular faculty. Research sample in the following studies might be comprised of business people, as well. Also, self-report 
studies are always vulnerable to biases. Thus, some rigorous experimental studies to observe real ethical business behaviours would produce more fruitful results. 


\section{REFERENCES}

Ajzen, I. (1985). From intentions to action: A theory of planned behavior. In J. Kuhl \& J. Beckmenn (Eds.), Action control: From cognition to behavior (pp. 11-39). New York: Springer.

Ajzen, I. (1991). The Theory of planned behavior. Organizational Behavior and Human Decision Processes, 50(2), 179-211.

Aytaç, M. \& Öngen, B. (2012). Doğrulayıcı faktör analizi ile yeni çevresel paradigma ölçeğinin yapı geçerliliğinin incelenmesi. İstatistikçiler Dergisi, 5, 14-22.

Banerjee, S. B. (2002). Corporate environmentalism: The construct and its measurement. Journal of business research, 55(3), 177-91.

Bechtel, R. B., Verdugo, V. C., \& de Queiroz Pinheiro, J. (1999). Environmental belief systems: United States, Brazil, and Mexico. Journal of Cross-Cultural Psychology, 30(1), 122-28.

de Anguita, P. M., Alonso, E., \& Martin, M. A. (2008). Environmental economic, political and ethical integration in a common decision-making framework. Journal of environmental management, 88(1), 15464.

Dubinsky, A. J., \& Loken, B. (1989). Analyzing ethical decision making in marketing. Journal of Business Research, 19(2), 83-107.

Dunlap, R. E. (1980). Paradigmatic change in social science: from human exemptions to an ecological paradigm. American Behavioral Scientist, 24(1), 5-14.

Dunlap, R. E., Van Liere, K. D., Mertig, A. G., \& Jones, R. E. (2000). New trends in measuring environmental attitudes: measuring endorsement of the new ecological paradigm: a revised NEP scale. Journal of Social Issues, 56(3), 425-42.

Erdogan, N. (2009), Testing the new ecological paradigm scale: Turkish case. African Journal of Agricultural Research, 4(10), 1023-31.

Ferrell, O. C., \& Gresham, L. G. (1985). A contingency framework for understanding ethical decision making in marketing. Journal of Marketing, 49(3), 87-96.

Flannery, B. L., \& May, D. R. (2000). Environmental ethical decision making in the US metal-finishing industry. Academy of Management Journal, 43(4), 642-62.

Gillian, C. (1993). In a Different Voice: Psychological Theory and Women's Development. Cambridge, MA: Harvard University Press.

Graham, J. W. (1986). Principled organizational dissent: A theoretical essay. Research in Organizational Behavior, 8, 1-52. 
Hair, J. F., Black, W. C., Babin, B. J., \& Anderson, R. E. (2010). Multivariate Data Analysis (7th Ed.), Pearson.

Hardin, G. (1968). The tragedy of the commons. Science, 162(3859), 1243-48.

Harmes, A. (2011). The limits of carbon disclosure: theorizing the business case for investor environmentalism. Global Environmental Politics, 11(2), 98-119.

Hunt, S. D. \& Vitell S. M. (1986). A general theory of marketing ethics. Journal of Macromarketing, 6, 5-15.

Işildar, G. Y. (2008). Meslek yüksekokullari boyutunda "çevre eğitimi"nin çevreci yaklaşımlar ve davranışlar üzerindeki etkilerinin değerlendirilmesi. Türk Ĕ̆itim Bilimleri Dergisi, 6(4), 759-778.

İnal, S. K. M. E., \& İnal, M. E. (2010). Yüksek öğretimde çevre eğitimi alan ve almayan öğrencilerde çevre bilinci: Niğde Üniversitesi örneği. Niğde Üniversitesi İktisadi ve İdari Bilimler Fakültesi Dergisi, 3(2), 70-83.

Jones, T. M. (1991). Ethical decision making by individuals in organizations: An issue- contingent model. Academy of Management Review, 16(2), 366-95.

Kohlberg, L. (1981). Essays in Moral Development: The Philosophy of Moral Development (Vol. 1). New York: Harper and Row.

Kopnina, H. (2014). If a tree falls: business students' reflections on environmentalism. International Journal of Innovation and Sustainable Development, 8(3), 311-29.

O'Fallon, M. J., \& Butterfield, K. D. (2005). A review of the empirical ethical decision-making literature: 1996-2003. Journal of Business Ethics, 59(4), 375-413.

Porter, M. \& Kramer, M. R. (2011). Creating Shared Value. Harvard Business Review, January-February, $1-17$.

Rest, J. R. (1986). Moral Development: Advances in Research and Theory. New York: Praeger.

Rutledge, R. W., \& Karim, K. E. (1999). The influence of self-interest and ethical considerations on managers' evaluation judgments. Accounting, Organizations and Society, 24(2), 173-84.

Strasser, K. A. (2011). Myths and Realities of Business Environmentalism: Good Works, Good Business or Greenwash?. Edward Elgar Publishing.

Tabachnick, B. G., \& Fidell, L. S. (2013) Using Multivariate Statistics (6th ed.) Boston: Pearson.

Thapa, B. (1999). Environmentalism: The relation of environmental attitudes and environmentally responsible behaviors among undergraduate students. Bulletin of Science, Technology \& Society, 19(5), $426-38$.

Trevino, L. K. (1986) Ethical decision making in organizations: A person-situation interactionist model. Academy of Management Review, 11(3), 601-17.

White, L. (1967). The historical roots of our ecologic crisis. Science, 155(3767), 1203-07. 